\title{
University Graduate Migration in Finland
}

\section{Authors}

Niina Kotavaara ${ }^{a}$,Ossi Kotavaara ${ }^{a}$, Jarmo Rusanen ${ }^{a}$, Toivo Muilu ${ }^{b}$

\section{Affiliations}

${ }^{a}$ Geography Research Unit, University of Oulu, P.O. Box 8000, 90014 University of Oulu, Finland

${ }^{b}$ Natural Resources Institute Finland, Paavo Havaksen tie 3, 90014 University of Oulu, Finland

\section{E-mail addresses}

niina.kotavaara@oulu.fi (N. Kotavaara), ossi.kotavaara@oulu.fi (O. Kotavaara), jarmo.rusanen@oulu.fi (J. Rusanen), toivo.muilu@luke.fi (T. Muilu)

\section{Corresponding author}

Niina Kotavaara

Geography Research Unit, University of Oulu

P.O. Box 8000, 90014 University of Oulu, Finland

niina.kotavaara@oulu.fi

+358408283940 


\title{
University Graduate Migration in Finland
}

\begin{abstract}
A high level of human capital is considered as an essential precondition for economic performance and regional competitiveness. However, university regions do not always manage to take advantage of the full potential of local higher education, as they are not always able to retain university students after graduation. Previous studies have presented remarkable regional differences concerning the share of graduates who remain in their university region after graduation. Hence, this paper has focused on geographical distribution and inter-regional mobility of university graduates in Finland. Long-term migration behaviour of all university graduates who completed their master's or equivalent degree in 2000-2015 was analysed using geographic information systems (GIS). The main finding of the paper is that university graduates in Finland are rather immobile, as the most active mobility takes places when transitioning from university to their first job. After that, the geographical distribution of the graduates is rather stable, which contradicts the general assumption of high mobility of university-educated people. Further, the migration flows are directed mainly towards the four largest city regions of the country, especially to the capital city region. Cross-migration between city regions with similar population sizes and population growth rate is marginal, and it seems that the difference in the population size and growth between the graduation region and the destination region has to be large enough to exceed the threshold for migration. Retaining university graduates seems to be especially challenging for the smallest and declining university regions.
\end{abstract}

Key words: Human capital, University graduates, Graduate migration, City Regions, GIS, Finland 


\section{Introduction}

Developed societies have become increasingly aware of the importance of higher education and human capital to the economic performance of countries and regions (e.g. Abel, Deitz, 2012, Faggian, Comunian et al., 2014, Faggian, McCann, 2009a, Fratesi, 2014, Krabel, Flöther, 2014). Higher levels of human capital have been linked to, for example, increases in population and employment growth, income level, innovation activity, long-run economic growth and regional productivity (Abel, Deitz, 2012, Benneworth, Herbst, 2015, Ciriaci, 2014). Regions are thus expected to benefit from investments in higher education, presupposing that highly educated people stay in university regions and enter local labour markets after graduation, increasing human capital levels of the regions (Abel, Deitz, 2011, 2012, Krabel, Flöther, 2014).

The migration behaviour of university graduates has become an increasingly important study subject of economic geography and economics. As the research literature related to the theme is limited, albeit growing, the previous studies do not yet offer a sufficient overall picture of the migration of university graduates. However, regardless of the country, there seems to be a general agreement that university graduates seem to flow towards economically growing regions and factors related to labour market characteristics of a region, as availability of jobs in the field of occupation, employment rate or wage level, seem to be key determinants affecting migration decisions of university graduates (e.g. Carree, Kronenberg, 2014, Ahlin et al., 2014, Venhorst et al., 2011, Di Cintio, Grassi, 2013, Dotti et al., 2013, Faggian, Corcoran, McCann, 2013, Krabel, Flöther, 2014).

In the Nordic context, migration of university graduates has been studied by, e.g. Ahlin, Andersson and Thulin (2014), Baltzopoulos and Broström (2015) and Tano (2014) for Sweden and Haapanen and Tervo (2012), Jauhiainen (2010), Kurikka (2008), Ritsilä and Haapanen (2003) and Suhonen (2013) for Finland. In Nordic countries mobility of highly educated people seems to be lower than assumed in mainstream theories of human capital, which is, at least partly, explained by the specific features of the countries. For example, Nordic welfare policy aims at ensuring equal living and housing environments and equal living standards for people regardless of place of residence (Raunio, 2001, Andersen et al., 2010). In the case of unemployment, Nordic states provide financial support for unemployed people to maintain a minimum standard of living 
(e.g. Asheim, Hansen, 2009). In addition, there is a long tradition of working women in Nordic countries, and the education and employment rates of women are high. Two wage earners in a family can be expected to lower mobility (Asheim, Hansen, 2009).

Finland has succeeded excellently in international rankings of global competitiveness, and its competitiveness is eminently based on the high quality of know-how and skills of the workforce and higher education that is among the best in the world (Schwab, 2016, Williams, Leahy et al., 2016). Finland differs remarkably from many European countries because, together with France and Norway, it has the densest university network covering the whole state territory (Neave, 2011). The establishment of the regional universities has been seen, above all, as an important means to promote economic development outside the core regions in Finland (Dhondt, Nevala, 2015). As a result of tightening international competition, economic restructuring and recent economic downturn, the Finnish government has cut investments in education and research. At the same time, the geographically dense university network has faced pressures to concentrating university education into fewer places. Investment cuts and shutting down of university units have raised critical discussion about their effects on the human capital level and the development of the competitiveness of the country, which underlines the importance of studying the mobility of the country's university-educated people.

Consequently, this paper contributes to the need in economic geography to expand and deepen the understanding of mobility of university graduates, by producing empirical evidence on the long-term, interregional migration behaviour of university graduates in Finland. Especially, the paper adds to knowledge on the migration behaviour of university graduates in the Nordic context, where the conditions of mobility are different than in other countries, as earlier described. Particular attention is given to the differences between city regions in attracting university-educated people and the effectiveness of university regions in retaining their graduates and, hence, producing a highly educated work force for the local labour market.

The article is structured as follows. Chapter 2 reviews the previous results concerning the mobility of highly educated people, focusing especially on university graduates. Chapter 3 introduces the university education system in Finland. The data and the methods of the article are described in Chapter 4. After that, in Chapter 
5, the results are presented. In the concluding Chapter 6, results are discussed regarding the migration pattern of university graduates and regional effectiveness of the universities in Finland and, further, how the results can be used to develop the knowledge-based regional competitiveness of the city regions in Finland.

\section{Mobility of university graduates}

While the migratory decisions of individuals, in general, is a well-studied theme, less is known about the migration behaviour of recent university graduates (Carree, Kronenberg, 2014).The university graduate migration has been studied especially in European countries (Kazakis, Faggian, 2016), whereas corresponding literature in U.S. (e.g. Abel, Deitz, 2011, 2012, Kazakis, Faggian, 2016, Kodrzycki, 2001, Whisler et al., 2008) is still less developed (Kazakis, Faggian, 2016). Some studies on the mobility of university graduates have appeared also in Asia (e.g. Ma et al., 2017 for South Korea and He et al., 2016 for China and Japan) and in Australia (e.g. Corcoran et al., 2010).

The research literature is still limited and therefore does not yet offer a sufficient overall picture of the migration behaviour of university graduates. Many of the previous studies concentrate, for example, on the time-period from graduation to first employment, on a specific group of university graduates (e.g. a specific region or a specific field), on specific indicators or on the impact of personal characteristics such as gender, age or ethnic group on migration decisions, and many of these studies have also been constrained by lack of high-quality data (Abreu et al., 2015, Faggian, Comunian et al., 2014, Haapanen, Tervo, 2012, Krabel, Flöther, 2014). In addition, Faggian, Corcoran and McCann (2013) point out, that most of the empirical indicators used in labour migration research have been either zero- or one-dimensional studying migration probabilities, linear distance measures or gravity model flows of labour, not taking into account that graduates move in geographical space between two particular places.

Despite above mentioned limitations, there is a common agreement among migration researchers that human capital, which is usually measured in the form of education, increases the probability of migrating (e.g. Belfield, Morris, 1999, Faggian, Comunian et al., 2014, Faggian, McCann, 2009a, Kodrzycki, 2001). 
Therefore, university graduates are considered highly mobile, and migration seems to play an important role in the geographic distribution of university graduates (Abel, Deitz, 2011, 2012, Faggian, McCann, 2009b). Further, Faggian and McCann (2009b) have found empirical evidence supporting the mobility of British university graduates by studying average moving distance from the university to the area of first employment, which, according to their results, is equivalent to moving across three or four travel-to-work areas. However, Faggian and McCann (2009b), as well as Belfield and Morris (1999), report significant regional differences in graduate mobility in the U.K.

Respectively, another part of the literature has found empirical evidence for showing that all university graduates are not mobile (e.g. Belfield, Morris, 1999 for U.K., Krabel, Flöther, 2014 for Germany, Haapanen, Tervo, 2012 for Finland). For example, the results of Belfield and Morris (1999) point to a remarkable group of British university graduates that never moves and to another group that moves back home after graduation. Krabel and Flöther (2014), in turn, consider German university graduates rather immobile, since about two out of five graduates, who finished their studies in 2007, remained in the university region. However, the share of stayers varied in different regions, as graduates of rural, urban and agglomeration regions were significantly more likely to leave the university region after graduation than graduates of metropolitan areas.

Haapanen and Tervo (2012) found evidence supporting immobility of Finnish university graduates. Their statistical analysis of long-distance inter-regional migration of university graduates in Finland was based on samples from 13 cohorts of graduates between 1991 and 2003. The data consisted of 4,373 graduates with a follow-up period until a graduate moves away from the region of studies, the last year of observation being 2004 and the maximum observed duration being 16 years. The analysis showed that most of the Finnish university graduates do not move from their region of studies within 10 years after graduation. The most active mobility takes place in the graduation year and following year, which is in line with the results of Hansen and Niedomysl (2009) concerning the migration activity of Swedish university-educated people.

Further, Haapanen and Tervo (2012) noticed higher out-migration, a so-called brain drain, in the more peripheral university regions than in the growth centres, especially in the capital city region. Respectively, by 
studying register data on graduates in Sweden in the year 2000, Ahlin, Andersson and Thulin (2014) found that almost two out of three graduates move after graduation to the three largest urban regions in Sweden. Similar migration flows of university graduates towards growth centres were found also in Italy (e.g. Ciriaci, 2014, Di Cintio, Grassi, 2013, Dotti et al., 2013, Fratesi, Percoco, 2014), in the Netherlands (e.g. Venhorst et al., 2010) and in U.K. (e.g. Faggian, McCann, 2009b).

Ahlin et al. (2014) point out two main arguments explaining the concentration of the highly educated workforce. The first argument emphasizes lifestyle amenities, such as cultural and recreational amenities (e.g. pubs, restaurants, theatres, museums, opera houses) or quality of social life (e.g. social diversity, openness, tolerance), offered by large city regions as key attractors for human capital (e.g. Florida, 2002a, 2002b, Glaeser, Gottlieb, 2006). Another argument supports the view that good employment opportunities are the most important factors affecting migration decisions of human capital (e.g. Niedomysl, Hansen, 2010, Scott, 2010, Storper, Scott, 2009).

Authors such as Carree and Kronenberg (2014), Ahlin et al. (2014), Venhorst et al. (2011), Di Cintio and Grassi (2013), Dotti et al. (2013), Faggian, Corcoran and McCann (2013), and Krabel and Flöther (2014), have found empirical evidence for the latter argument by studying university graduates. They have shown that factors related to labour market characteristics of the region, such as regional economic growth, job availability, employment rate or wage level, affect the migration decisions of university graduates. Further, Faggian and McCann (2009a) particularize that, as a two-dimensional phenomenon, the migration is always related to the economic attractiveness of the destination region in comparison to the origin region. Nifo and Vecchione (2014), however, remind that objectives behind migration decisions of university graduates are more complex than only ensuring a higher income and better job opportunities. The graduates search for higher 'quality of life' consisting of a mix of economic, social and cultural factors related to economic welfare, job opportunities and social mobility.

In addition to the importance of economic and labour market-related chacateristics of the university regions in attracting a university-educated workforce from elsewhere, the results of Krabel and Flöther (2014) underline their influence on the ability of the university regions to retain their students after graduation. As 
Venhorst et al. (2011: 75) puts it "regions that are doing relatively well economically are more likely to retain local graduates". Faggian and McCann (2009b) made the same observation as they found that the strength of local labour market spillovers of the British universities was largely dependent on the strength of the local economy. Consequently, policies that aim at increasing the human capital level of a region should focus both on supply and demand of university-educated people in the local labour market (Abel, Deitz, 2012, Faggian, McCann, 2009b).

\section{University education in Finland}

Finland has some 5.5 million inhabitants, of which $45 \%$ live in the four largest city regions (Statistics Finland 2016). Finland has experienced a trend of urbanization since the 1950's, several decades later than other Europe. However, the urbanization process has been fast due rapid change of economic structure and growth of labour markets in cities. The capital region is the only city region in Finland with more than one million inhabitants (1.5 million); $27 \%$ of the population of the country live in the area. The other three biggest city regions have less than 400000 inhabitants (Statistics Finland, 2016). The country is sparsely populated, cities are relatively small and they are mainly located far from each other.

Regardless of the above-mentioned facts, Finland has succeeded excellently in international global competitiveness rankings. Despite that Finland has experienced a decline in its competitiveness during recent years, it is still 10th in the World Economic Forum global competitiveness ranking 2016-2017. One part of the foundation of Finland's competitiveness, according to the World Economic Forum, is a higher education and training system that is among the best in the world (Schwab, 2016). Respectively, Universitas 21, a global network of research-intensive universities, ranked Finland's national system of higher education the sixth best in the world, in the annual ranking 2016, of 50 national systems in four areas: resources, environment, connectivity and output (Williams, Leahy et al., 2016).

In Finland, higher education is free of charge and equal access to higher education is ensured in many ways (e.g. student financial aid). Together $43 \%$ of the 25-64-year-old population has a tertiary education, which 
is above the OECD (Organisation for Economic Co-operation and Development) average (OECD, 2016). The Finnish system of higher education consists of 14 universities, six university consortiums (Figure 1) and 26 universities of applied sciences. Based on statistics of 2014, there is some 302000 university students in Finland, of which $54 \%$ studied at universities and $46 \%$ at universities of applied sciences (Statistics Finland, 2015). Universities and universities of applied sciences produce an average of 52000 people with higher education degrees every year (Statistics Finland, 2015).

As part of the European trend, Finland expanded its university network from the 1950's to 1980's and Finland was one of the European countries where quantitative development of universities was remarkable (Neave, 2011). The number of university students expanded after the Second World War from about 10000 to about 180000 students during the millennium (Salo, 2015). Finland, together with France and Norway, has a university network that most densely covers the entire state territory in Europe (Neave, 2011). Establishment of "provincial" universities was an important means in promoting regional development outside the core regions of the countries (e.g. Dhondt, Nevala, 2015). Unlike, for example Sweden and Norway, which invested in polytechnics/regional colleges, Finland invested in science universities (Kohvakka, 2013).

The university sector consists of multi-faculty universities, universities of technology, business schools and art academies. Two of them are foundations and the rest are public corporations. In addition, university-level education is provided at the Military Academy, the National Defence University, which is part of the Defence Forces. Although, the universities have independent legal status and they have been separated from the state since 2010, the state is still the primary financier of the universities and direct government funding covers about $60 \%$ of university budgets. In addition, universities need to acquire private donations (Eurydice, 2017). Based on the legislation (Ministry of Justice, 2014), field-specific educational responsibilities of the universities are defined by the decree of the Ministry of Education and Culture (2014) which has been prepared in collaboration between the ministry and the universities. On the basis of the negotiations, the universities then decide on their student intake in agreed educational fields (Eurydice, 2017). 
As a result of tightening international competition, economic restructuring and recent economic downturn, the Finnish government recently cut investments in education and research. At the same time, the geographically dense university network has faced pressures to concentrate university education into fewer places. Investment cuts and shutting down of university units have raised critical discussion about their effects on the human capital level and the development of the country's competitiveness, which underlines the importance of studying the mobility of Finland's university-educated people.

[FIGURE 1 ABOUT HERE]

\section{Material and methods}

Analyses of this study are based on the individual-level rasterized locational data of university graduates, which is designed in cooperation and produced by Statistics Finland. In addition, the open source GIS data of population and population change, the administrative Finnish city regions and the city centre points, as well as the road network in Finland were applied. A coordinated dataset of university graduates is compiled by Statistics Finland on the basis of three different datasets: 'Education Statistics Locational Data', 'Register of Completed Education and Degrees' and 'Population Structure'. Geographical distribution of university graduates and its temporal change are analysed by forming spatial aggregations at the $5 \times 5 \mathrm{~km}$ grid cell level and at the city region level and by counting the cumulative sum of the degrees by road distance to graduation city region (Figure 2).

\section{[FIGURE 2 ABOUT HERE]}

The university graduation data includes those who completed their master's or equivalent degree (ISCED 2011) in Finland between years 2000-2015, excluding graduates who migrated internationally. First, the graduation data is connected to the locational information of the graduation universities. The data covers all of the country's university units apart from those university consortiums which provide only small-scale education (around $0.5 \%$ of the original data). Second, the graduation data is connected to the residential history of university graduates after one, five and ten years of graduation and in 2015. The spatial accuracy 
of residential information is generalized to the resolution of $5 \times 5 \mathrm{~km}$ grid cells. One year after graduation represents migration from the graduation university to the first employment opportunity following graduation. A more stable housing pattern is already apparent five and ten years after graduation in relation to the job markets in Finland. The graduates without locational information on their residential history were excluded. Therefore, the final data cover 202783 degrees, i.e. $98.7 \%$ of the university graduates in 20002015 residing in Finland (Table 1).

\section{[TABLE 1 ABOUT HERE]}

Due to Finnish privacy protection legislation regulating availability of public register records, information related to individual citizens or individual educational units is not allowed to be published. Hence, the privacy protection of the university graduates and the university units is conducted in two phases. First, Statistics Finland has recoded the person-specific information to randomized table key and the university unit-specific information to the anonymous university unit data with municipal-level locational information. Second, the results have to be aggregated to $5 \times 5 \mathrm{~km}$ grid cells and at the city regional level by the graduation city regions and the residential city regions classified according to the population (Table 2) and the population change (Table 3), by using the open source GIS data of Statistics Finland and the data of Finnish Environmental Institute.

\section{[TABLE 2 ABOUT HERE]}

[TABLE 3 ABOUT HERE]

To explore the spatial distribution of the university graduates on a more accurate scale, but still following privacy protection restrictions, the cumulative sum of university graduates, which are aggregated at the city regional level, is calculated in relation to the road distance between the residential location in 2015 and the centre of the graduation city region (Figure 2). In the distance estimation, the Finnish road network data, Digiroad (Finnish Road Administration), and the indicative city centre points obtained from the Geographic Location Name dataset (NLS, National Land Survey of Finland) were applied. 


\section{Results}

\subsection{Degree production and the net migration of university graduates}

Regardless of the territorially dense and decentralized university network, the migration pattern of university graduates has evidently a centralized form in Finland. Like highly educated people in general, the university graduates in 2000-2015 are mainly concentrated in the largest city regions of the country. Around $66 \%$ of the university graduates who completed their master's or equivalent degree in 2000-2015 lived in the four biggest Finnish city regions (Helsinki, Tampere, Turku and Oulu) one year after graduation and, moreover, a majority of them lived in the capital city region (Table 4, Figure 3).

\section{[FIGURE 3 ABOUT HERE]}

\section{[TABLE 4 ABOUT HERE]}

It is highly noteworthy that the biggest city regions' shares of housing of all the university graduates did not decrease remarkably within five or ten years after graduation, which refers to a rather stable migration pattern. Further, even though Finland is often described as "a rural or sparsely populated country", only a minor share $(5 \%)$ of the graduates live outside administrative city regions. This finding pertains to the housing pattern of university graduates at all points of time after graduation (Table 4, Figure 3 ).

As city regions are competing for human capital, it is notable that the capital city region gains nine percentage points more university-educated people than it produces, when considered by the net migration at the national level. The capital city region produced $33 \%$ of the country's university graduates in 2000-2015, but after graduation around $42 \%$ of all the university graduates lived in the capital city region. Hence, the capital region benefits remarkably from the higher education institutions of the other regions. Whereas the capital city region wins university graduates from the other city regions, and especially the large ones lose university graduates when compared to degree production. The large city regions produced $34 \%$ of all the university graduates in 2000-2015, but after five years of graduation only $23 \%$ of all the graduates lived in the regions (Table 4). 


\subsection{Retaining university graduates}

For regional competitiveness it is, however, important that the region is able to retain its university graduates after graduation (e.g. Abel, Deitz, 2011, 2012, Krabel, Flöther, 2014). In Finland about half of the university graduates stay in the same city region as the university after graduation, and the migration pattern seems to be rather stable. The share of the stayers was $55.3 \%$ after one year and still $49.0 \%$ after ten years. The results do not show signs of re-migration to the graduation city regions afterwards. Thus, once the university graduates are lost, they rarely later move back to the graduation city regions. On this basis, the most critical moment for the city regions, in competing for locally educated university graduates, seems to be immediately after graduation.

However, there are significant differences between different types of city regions, and retaining university graduates seems to be especially challenging for the other city regions than the capital city region, which is economically the most diverse and the fastest growing city region of the country, and also the only net winner of the university graduates in the country. In the capital city region more than $80 \%$ of university students still lived in the region one year after graduation, and almost $80 \%$ of the university educated people, that graduated in the capital city region ten years ago, were still there (tables 5-6). In other words, those who go to the capital city region to study are likely to stay there at least ten years after graduation.

For the other city regions the maximum share of stayers was a little over half of the graduates, and the larger the city region and the faster the population growth, the larger the share of the stayers. The smallest city regions, as well as the declining city regions, lost about $80 \%$ of their university graduates or even more. The temporal inspection shows that for all the city regions the greatest outflow happens at the time of the first employment and the outflow after that is substantially weaker. This proves, again, the importance of the ability of the city region to retain its university graduates immediately after graduation (tables 5-6). What is noteworthy is that having a university in the city region is not a sufficient precondition for obtaining a highly educated workforce. 


\section{[TABLE 6 ABOUT HERE]}

\subsection{Inter-regional cross-migration of university graduates}

Accordingly, the results show that the cross-migration between the same-sized city regions or between the city regions with same population growth rate is rather low and it seems that the difference in the size and the growth rate between the graduation city and the destination city region has to be large enough to exceed the threshold for migration of university graduates. For instance, only some of the graduates move between the city regions of Oulu, Tampere and Turku (i.e. large city regions), since the most common choice of university graduates in the large city regions is to stay in the same city region or, as a second common option, to move to the capital city region. The same applies to the moderately and slowly growing city regions (tables 5-6). In other words, it seems that the graduates do not move to a city-region that is only a little bigger or grows a little faster than the city region where they studied. Instead, they prefer moving to a city-region that is significantly bigger or grows significantly faster. Generally speaking, in this sense, they jump over one city-regional level in the categorizations of this study.

Within the medium-sized city regions and the declining city regions, the share of university graduates who move to the capital city region is even larger than the share of the stayers. What is noteworthy is that the graduates do not move from the medium-sized city regions to the large city regions. Correspondingly, university graduates do not move from the small city regions to the middle-sized city regions. Instead, within the small-city regions the most common choice is to move to the large city regions or, almost as common, to the capital city region or to stay in the graduation city region. Further, university graduates rarely move from the declining city regions to slowly growing city regions, as the more common choices are moving to the capital city region or to moderately growing city regions or staying in their graduation city region (tables 5$6)$.

The middle-sized and the small city regions gains most of their university graduates from other regions, as the local university education is often too specialized to meet local labour needs. The share of the regionally produced graduates is $38.3 \%$ in the middle-sized city regions and $30.8 \%$ in the small city regions. The share 
of the regionally produced graduates is largest one year after graduation, and after ten years, for example, in the small city regions only every fourth $(24.7 \%)$ university graduate is regionally produced. The share is largest in the large city regions where about three out of four $(75.3 \%)$ university graduates are regionally produced one year after graduation. In the capital city region the share is smaller (64.8\%), but the difference becomes more even in time.

The small city regions gain university-educated people rather evenly from the large city regions, the middlesized city regions and their own university units, but for the first two mentioned the outflow to the small city regions is, relatively speaking, insignificant (Table 5). The declining and the slowly growing city regions get their university graduates from their own university units or from the moderately growing city regions. For the moderately growing city regions, the outflow to the declining and the slowly growing city regions is, however, only about five percent or less of the graduates (Table 6).

The city regions which do not have university units or they provide only small-scale university education, gain a rather minor share of all university graduates. Their university-educated people have, measured in absolute numbers, mainly graduated in the middle-sized and moderately growing city regions. However, relatively speaking, moving to 'other city regions' is most common for university graduates who graduated in the middle-sized or small city regions that are growing slowly or declining (tables 5-6).

The areas located outside the administrative city regions (i.e. small towns and rural areas) are, in getting a university-educated workforce, dependent mainly on the large and middle-sized city regions and the city regions that are moderately growing. However, moving outside the city regions was, relatively speaking, most common among the university graduates who graduated in the small city regions and the city regions which are mainly slowly growing (Table 5).

\subsection{Spatial (im)mobility and moving distances of university graduates}

Finally, the strength of the city regions' attraction is considered on the basis of the share of the university graduates accumulating in relation to road distance between the centre of the graduation city region and year 
2015 residential locations at a scale of $5 \times 5$ grid cells. Each city region is represented by the core point of its dominant city. Due to privacy protection, city regions are aggregated into four classes. In general, the average distance between a residential place of graduates and graduation city is $132.8 \mathrm{~km}$ with a standard deviation of 169.6 when the minimum is $0.1 \mathrm{~km}$ (small values are highly biased or inaccurate due to the grid cell resolution) and maximum is $1316.0 \mathrm{~km}$ (Figures 4-5).

\section{[FIGURE 4 ABOUT HERE]}

\section{[FIGURE 5 ABOUT HERE]}

However, as Figure 4 shows, in the capital city region and the large city regions, a remarkable share of the graduates are residing within the core and the suburbs of the dominant city. For example, $69.6 \%$ of the graduates from the capital city region live within $20 \mathrm{~km}$ of the city centre, while $44.4 \%$ of the graduates from the large city regions live within the same distance. The middle-sized city regions and the small city regions have clearly a much more dispersed migration pattern of university graduates due to out migration. Within the same $20 \mathrm{~km}$ distance, the middle-sized city regions contain $11.9 \%$ of graduates and the small city regions $14.8 \%$. In this respect, the attractiveness of the capital city region is thoroughly more intense than of the other city regions in Finland.

When distances between residential places and graduation cities of university graduates is viewed as cumulative shares of university graduates of different types of city regions within all university graduates (all observations), the actual volumes of the city regions become more visible (Figure 5). The volumes and the migration patterns of the capital city region and the large city regions are mainly similar. However, the capital city region has attracted a great deal of university graduates from the large city regions, which is visible as clear drops in the curve of the large city regions. In the national framework, the small city regions produce a relatively small share of university graduates, and they are strongly dispersed around the country. Half of these graduates reside within $210.4 \mathrm{~km}$ from a graduation city centre. 


\section{Conclusions}

A high level of human capital is considered as an essential precondition for economic performance and regional competitiveness. However, university regions do not always manage to take advantage of the full potential of local higher education, as they are not always able to retain university students after graduation. Previous studies have presented remarkable regional differences concerning the share of graduates who remain in their university region after graduation. In the Nordic context, due to limited research literature, a wider understanding of migration behaviour of university graduates is still insufficient.

Hence, this paper has focused on geographical distribution and inter-regional mobility of the university graduates in Finland. Long-term migration behaviour of all the university graduates who completed their master's or equivalent degree in 2000-2015 was analysed using GIS. Particular attention was given to the differences between city regions in attracting university-educated people and the effectiveness of the university regions in retaining their graduates and, hence, producing a highly educated work force for the local labour market.

Finnish university graduates seem to be rather immobile, as about half of the university graduates stay in the region where they studied. Basically, the larger the city region and the faster the population growth, the larger the share of the stayers. Given the research time points of this study, the mobility of the graduates is highest during the first year after graduation and the geographical distribution of the graduates seems to be quite stable by the end of the first year.

The results contradict the general assumption of high mobility of university-educated people, but on the other hand, they are in line with the previous results of Haapanen and Tervo (2012) concerning university graduates in Finland. In general, the results confirm a less visible view in the literature that all university graduates are not mobile. There are some contextual factors that explain the immobility of the university graduates in Finland, e.g. small number of cities that the graduates can move between, national welfare policy that aims, for example, to lower regional differences and ensure equal living standards in every region, as well as provide financial support for unemployed people, and high share of dual career families. 
The results also emphasize the importance of the ability of a university region to retain its university graduates immediately after graduation, as underlined in the literature (e.g. Abel, Deitz, 2011, 2012, Krabel, Flöther, 2014).

In accordance with the ongoing urbanization process of the country and the international trend of human capital flowing towards economically diverse and successful regions with better employment opportunities, university graduates are mainly (66\%) concentrated in the four largest city regions (Helsinki, Turku, Tampere and Oulu) of the country and, moreover, a majority (a little over $40 \%$ ) of them end up in the capital city region, which is economically the most diverse and the fastest growing city region of the country, and the only net winner of the graduates. Moreover, those who go to the capital city region to study seem to be likely to stay there, with the retention rate of the capital city region being about $80 \%$. Surprisingly, the cross-migration between the biggest city regions, except for the capital city region, is marginal. Explaining the phenomenon needs further research.

Retaining and attracting university graduates seems to be especially challenging for the smallest and declining university regions. Thus, having a geographically dense and decentralized university network is not a sufficient precondition for providing a highly educated workforce for regions. Based on previous studies, retaining university graduates requires also availability of jobs and good regional economic performance.

In their study on the migration of Finnish university graduates, Haapanen and Tervo (2012) asked an important question concerning the ability of regions without a university to attract graduates. Based on the results of this paper, the regions which do not have university units gain only a minor share of all university graduates. However, except for the most rural areas, compared to the smallest and demographically declining university regions, they manage to attract graduates relatively well. As the results are on an aggregated level, further research is needed in order to clarify regional differences concerning effects that concentrating university education into fewer places would have on human capital stocks of those regions which would lose their university unit. As the outflow of university graduates is partly based on field-specific educational responsibilities of universities, defined by the state government, additional research is also needed concerning the effects of out-migration on the compatibility of university education and field-specific human 
capital stocks in the regions that are net losers of university graduates, i.e., all regions except for the capital city region.

The key benefit of analysing migration patterns of Finnish university graduates with the coordinated data and GIS framework, was the ability to identify and scrutinize in and out migration patterns of the graduates with origin and destination locations. Due to the comprehensive data, migration flows were distinctly measured. Recognizing and explaining causalities behind the observed trends were left for further research. This, however, will be a highly complicated task as various pushing and pulling factors simultaneously influence migration decisions. In addition, whereas this study analysed graduates as a homogenous group, further research that takes into account heterogeneity of university graduates is needed. For example, the differences in migration behaviour of the graduates in different fields are unavoidable, as some degree programmes are arranged in several universities, whereas some degree programmes are available only at a single university. The scientifically produced information on the above-mentioned differences would have a high practical value when applied to developing the field-specific educational responsibilities of the universities. Although this study considered only the subnational migration of university graduates, international migration flows of university-educated people, moving in and out of Finland, constitutes an additionally relevant research theme, to which the methodology of this study could be applied directly.

Finally, some important policy implications can be derived from the key findings of the study. First, the results reinforce the policy implications of Haapanen and Tervo (2012) concerning the consequences of concentrating university education into fewer places. As they consider, this might lead towards more centralized economical structures. This kind of policy would be in clear contradiction with traditional Finnish policies of ensuring equal regional development. Second, policies aimed at raising regional human capital levels by a geographically dense university network are not sufficient in providing a highly educated workforce for regions. Policies should, instead, focus on supporting and developing both supply and demand of university graduates. Third, the marginal cross-migration of the graduates between the regions with similar population size and population growth rate should be taken into account in the defining of fieldspecific educational responsibilities of the university regions. Fourth, the immobility of university graduates, after their first employment, emphasizes that a university region should be able to retain its university 
students immediately after they graduate. This could even be summarized as follows: “Once they're gone, they're lost".

\section{References}

Abel, J.R., Deitz, R., 2011. The Role of Colleges and Universities in Building Local Human Capital. Current Issues in Economics and Finance 17 (6), 1-7.

Abel, J.R., Deitz, R., 2012. Do Colleges and Universities Increase Their Region's Human Capital? Journal of Economic Geography 12 (3), 667-691.

Abreu, M., Faggian, A., McCann, P., 2015. Migration and Inter-Industry Mobility of UK Graduates. Journal of Economic Geography 15 (2), 353-385.

Ahlin, L., Andersson, M., Thulin, P., 2014. Market Thickness and the Early Labour Market Career of University Graduates: An Urban Advantage? Spatial Economic Analysis 9 (4), 396-419.

Andersen, K.V., Bugge, M.M., Hansen, H.K., Isaksen, A., Raunio, M., 2010. One Size Fits All? Applying the Creative Class Thesis onto a Nordic Context. European Planning Studies 18 (10), 1591-1609.

Asheim, B., Hansen H. K., 2009. Knowledge Bases, Talents, and Contexts: On the Usefulness of the Creative Class Approach in Sweden. Economic Geography 85 (4), 425-442

Baltzopoulos, A., Brostrom, A., 2013. Attractors of Entrepreneurial Activity: Universities, Regions and Alumni Entrepreneurs. Regional Studies 47 (6), 934-949.

Belfield, C., Morris, Z., 1999. Regional Migration to and from Higher Education Institutions: Scale, Determinants and Outcome. Higher Education Quarterly 53 (3), 240-263.

Benneworth, P., Herbst, M., 2015. The City as a Focus for Human Capital Migration: Towards a Dynamic Analysis of University Human Capital Contributions. European Planning Studies 23 (3), 452-474.

Carree, M.A., Kronenberg, K., 2014. Locational Choices and the Costs of Distance: Empirical Evidence for Dutch Graduates. Spatial Economic Analysis 9 (4), 420-435.

Ciriaci, D., 2014. Does University Quality Influence the Interregional Mobility of Students and Graduates? The Case of Italy. Regional Studies 48 (10), 1592-1608.

Corcoran, J., Faggian, A., Mccann, P., 2010. Human Capital in Remote and Rural Australia: The Role of Graduate Migration. Growth and Change 41 (2), 192-220.

Dhondt, P., Nevala, A., 2015. The Typical Dilemma Between University Expansion and Rationalization: Belgium (and Finland) since the 1960s. Kasvatus \& Aika 9 (3), 21-36.

Di Cintio, M., Grassi, E., 2013. Internal Migration and Wages of Italian University Graduates. Papers in Regional Science 92 (1), 119-140. 
Dotti, N.F., Fratesi, U., Lenzi, C., Percoco, M., 2013. Local Labour Markets and the Interregional Mobility of Italian University Students. Spatial Economic Analysis 8 (4), 443-468.

Drucker, J., 2016. Reconsidering the Regional Economic Development Impacts of Higher Education Institutions in the United States. Regional Studies 50 (7), 1185-1202.

Eurydice, 2017. Higher education. https://webgate.ec.europa.eu/fpfis/mwikis/eurydice/index. php/Finland:Higher_Education (accessed 13.2.2017).

Faggian, A., Comunian, R., Li, Q.C., 2014. Interregional migration of human creative capital: The case of "Bohemian graduates". Geoforum 55, 33-42.

Faggian, A., Corcoran, J., McCann, P., 2013. Modelling Geographical Graduate Job Search Using Circular Statistics. Papers in Regional Science 92 (2), 329-343.

Faggian, A., McCann, P., 2009a. Human capital and regional development. In: Capello, R., Nijkamp, P. (Eds.) Handbook of Regional Growth and Development Theories. Edward Elgar Publishing Limited, Cheltenham, pp. 133-151.

Faggian, A., McCann, P., 2009b. Universities, Agglomerations and Graduate Human Capital Mobility. Tijdschrift voor economische en sociale geografie 100 (2), 210-223.

Florida, R., 2002a. The Economic Geography of Talent. Annals of the Association of American Geographers $92(4), 743-755$.

Florida, R., 2002b. The Rise of the Creative Class: And How It's Transforming Work, Leisure, Community and Everyday Life. Basic Books, New York.

Fratesi, U., 2014. Editorial: The Mobility of High-Skilled Workers - Causes and Consequences. Regional Studies 48 (10), 1587-1591.

Fratesi, U., Percoco, M., 2014. Selective Migration, Regional Growth and Convergence: Evidence from Italy. Regional Studies 48 (10), 1650-1668.

Glaeser, E.L., Gottlieb, J. D., 2006. Urban Resurgence and the Consumer City. Urban Studies 43 (8), 12751299.

Goldstein, H., Renault, C., 2004. Contributions of universities to regional economic development: A quasiexperimental approach. Regional Studies 38 (7), 733-746.

Haapanen, M., Tervo, H., 2012. Migration of the Highly Educated: Evidence from Residence Spells of University Graduates. Journal of Regional Science 52 (4), 587-605.

Hansen, H. K., Niedomysl, T., 2009. Migration of the Creative Class: Evidence from Sweden. Journal of Economic Geography 9 (2), 191-206.

He, Z., Zhai, G., Asami, Y., Tsuchida, S., 2016. Migration Intentions and Their Determinants: Comparison of College Students in China and Japan. Asian and Pacific Migration Journal 25 (1), 62-84.

Huggins, R., Johnston, A., 2009. The economic and innovation contribution of universities: a regional perspective. Environment and Planning C 27 (6), 1088-1106.

Jauhiainen, S., 2010. Studies on Human Capital Flows and Spatial Labout Markets. Jyväskylä Studies in Business and Economics 94. 
Kazakis, P., Faggian, A., 2016. Mobility, Education and Labor Market Outcomes for U.S. Graduates: Is Selectivity Important? The Annals of Regional Science, 1-28.

Kodrzycki, Y.K., 2001. Migration of Recent College Graduates: Evidence from the National Longitudinal Survey of Youth. New England Economic Review 1 (1), 13-14.

Kohvakka, M., 2013. Verkosto, skaala ja korkeakoulujen perustaminen 1960-luvun alun Suomessa (Network, Scale and Establishment of Universities in the Early 1960's in Finland) (in Finnish). Alue ja ympäristö 42 (2), 3-16.

Krabel, S., Flöther, C., 2014. Here Today, Gone Tomorrow? Regional Labour Mobility of German University Graduates. Regional Studies 48 (10), 1609-1627.

Kuusela, K., 2016. Työllisyyskatsaus, kesäkuu 2016 (Employment Review, June 2016) (in Finnish). http://urn.fi/URN:NBN:fi-fe2016062121928 (accessed 24.8.2017).

Kurikka, H., 2008. Suomen yliopistoista valmistuneiden alueellinen sijoittuminen 1990-luvulta 2000-luvulle (Spatial Distribution of Graduates from Finnish Universities from the 1990s to the 2000s) (in Finnish). University of Oulu, Department of Geography, Oulu.

Lendel, I., 2010. The Impact of Research Universities on Regional Economies: The Concept of University Products. Economic Development Quarterly 24 (3), 210-230.

Ma, K-R., Kang, E-T., Kwon, O-K., 2017. Migration Behavior of Students and Graduates Under Prevailing Regional Dualism: The Case of South Korea. Annals of Regional Science 58 (1), 209-223.

Ministry of Education and Culture, 2014. Opetus- ja kulttuuriministeriön asetus 1451/2014 yliopistojen koulutusvastuun täsmentämisestä (Ministry of Education and Culture Decree 1451/2014 on Particularizing Educational Responsibilities of Universities) (in Finnish). http://www.finlex.fi/fi/laki/alkup/2014/20141451 (accessed 13.2.2017).

Ministry of Justice, 2014. Laki yliopistolain muuttamisesta 1172/2014 (Law on Amending the University Act 1172/2014) (in Finnish). http://www.finlex.fi/fi/laki/alkup/2014/20141172 (accessed 25.8.2017).

Neave, G., 2011. Patterns. In: Rüegg, W. (Ed.) A History of the University in Europe. Volume 4: Universities since 1945. Cambridge University Press, Cambridge, pp. 31-69.

Niedomysl, T., Hansen H. K., 2010. What Matters more for the Decision to Move: Jobs versus Amenities. Environment and Planning A 42 (7), 1636-1649.

Nifo, A., Vecchione, G., 2014. Do Institutions Play a Role in Skilled Migration? The Case of Italy. Regional Studies 48 (10), 1628-1649.

OECD, 2016. Education at a Glance 2016. http://www.oecd.org/edu/education-at-a-glance-19991487.htm (accessed 24.8.2017).

Raunio, M., 2001. Osaajat valintojen kentällä: Helsingin, Tampereen, Turun, Jyväskylän, Porin ja Seinäjoen seutujen vetovoimaisuus virtaavassa maailmassa (Professionals on the Field of Choice: The Attractiveness of Helsinki, Tampere, Turku, Jyväskylä, Pori and Seinäjoki Regions in a Flowing World) (in Finnish).

University of Tampere, Research Unit for Urban and Regional Development Studies, Tampere.

Ritsilä, J., Haapanen, M., 2003. Where Do the Highly Educated Migrate? Micro-Level Evidence from Finland. International Review of Applied Economics 17 (4), 437-448. 
Salo, M., 2015. Julkisten peruspalveluiden rakentamisesta teknologia-aaltoon: Suomen yliopistollisten koulutusalojen määrällinen kehitys 1950-luvulta 2010-luvulle (From Building of Basic Public Services into the Technology Wave: The Quantitative Development of Academic Fields in Finland from the 1950s to the 2010s) (in Finnish). Kasvatus \& Aika 9 (3), 211-243.

Schwab, K. (Ed.), 2016. The Global Competitiveness Report 2016-2017.

https://www.weforum.org/reports/the-global-competitiveness-report-2016-2017-1 (accessed 24.8.2017).

Scott, A. J., 2010. Jobs or Amenities? - Destination Choices of Migrant Engineers in the USA. Papers in Regional Science 89 (1), 43-63.

Statistics Finland, 2016. Official Statistics of Finland (OSF): Population structure.

http://www.stat.fi/til/vaerak/index_en.html (accessed 13.2.2017).

Statistics Finland, 2015. Official Statistics of Finland (OSF): Students and qualifications of educational institutions. http://www.stat.fi/til/opiskt/tau_en.html (accessed 13.2.2017).

Storper, M., Scott, A. J., 2009. Rethinking Human Capital, Creativity and Urban Growth. Journal of Economic Geography 9 (2), 147-167.

Suhonen, T., 2013. Studies on Higher Education Choices and Spatial Labour Markets. Jyväskylä Studies in Business and Economics 138.

Tano, S., 2014. Regional Clustering of Human Capital: School Grades and Migration of University Graduates. Annals of Regional Science 52 (2), 561-581.

Venhorst, V., Van Dijk, J., Van Wissen, L., 2011. An Analysis of Trends in Spatial Mobility of Dutch Graduates. Spatial Economic Analysis 6 (1), 57-82.

Venhorst, V., Van Dijk, J., Van Wissen, L., 2010. Do the Best Graduates Leave the Peripheral Areas of the Netherlands? Tijdschrift voor economische en sociale geografie 101 (5), 521-537.

Whisler, R. L., Waldorf, B. S., Mulligan, G. F., Plane, D. A., 2008. Quality of Life and the Migration of the College-Educated: A Life-Course Approach. Growth and Change 39 (1), 58-94.

Williams, R., Leahy, A., De Rassenfosse, G., Jensen, P., 2016. U21 Ranking of National Higher Education Systems. Universitas 21, Birmingham. 


\section{Figure captions}

Fig. 1. Location of Finnish university units. Finland's 14 universities have campuses in 11 city regions. In addition, other university units operate in nine city regions that do not have their own universities.

Fig. 2. Schematic work flow of the data sources, the data management, the key analyses and the results.

Fig. 3. Geographical distribution of the university graduates, who completed their master's or equivalent degree between the years 2000-2015, in $2015(\mathrm{~N}=203865)$.

Fig. 4. Cumulative share of university graduates within aggregation groups in relation to the distance between the residential location in 2015 and the centre of the graduation city.

Fig. 5. Cumulative share of university graduates by aggregation groups within all observations in relation to the distance between the residential location in 2015 and the centre of the graduation city. 
Table 1.

Number of university graduates who completed their master's or equivalent degree in 2000-2015.

\begin{tabular}{cccccc} 
All university & $\begin{array}{c}\text { University } \\
\text { graduates } \\
\text { graduates } \\
\text { with locational } \\
\text { data } \\
2000-2015\end{array}$ & $\begin{array}{c}\text { University } \\
\text { graduates } \\
\text { with locational data } \\
2000-2015,\end{array}$ & $\begin{array}{c}\text { University } \\
\text { graduates } \\
\text { university consortiums } \\
\text { providing small-scale } \\
\text { education excluded }\end{array}$ & $\begin{array}{c}\text { University } \\
\text { locational data, } \\
\text { 1 year } \\
\text { after graduation }\end{array}$ & $\begin{array}{c}\text { University } \\
\text { graduates }\end{array}$ \\
$\begin{array}{c}2000-2010 \\
\text { with locational } \\
\text { data, 5 years } \\
\text { after graduation }\end{array}$ & $\begin{array}{c}\text { 2000-2005 } \\
\text { with locational } \\
\text { data, 10 years } \\
\text { after graduation }\end{array}$ \\
\hline 205539 & 203865 & 202783 & 187968 & 135642 & 67791 \\
\hline
\end{tabular}


Table 2.

The classification of the data according to the size of the city region. Source (population): Statistics Finland (2016).

\begin{tabular}{lllccc}
\hline $\begin{array}{l}\text { Classification by } \\
\text { the size of the } \\
\text { city regions }\end{array}$ & $\begin{array}{l}\text { Population } \\
31.12 .2015\end{array}$ & City regions & $\begin{array}{c}\text { All university } \\
\text { graduates } \\
2000-2015\end{array}$ & $\begin{array}{c}\text { University } \\
\text { graduates with } \\
\text { locational data } \\
2000-2015\end{array}$ & $\begin{array}{c}\text { Share (\%) of } \\
\text { all university } \\
\text { graduates } \\
2000-2015\end{array}$ \\
\hline $\begin{array}{l}\text { Capital } \\
\text { city region }\end{array}$ & 1.4 million & Helsinki & 67360 & 66500 & 32.8 \\
$\begin{array}{l}\text { Large } \\
\text { city regions }\end{array}$ & $\begin{array}{l}200001- \\
400000\end{array}$ & Tampere, Turku, Oulu & 69914 & 69468 & 34.0 \\
$\begin{array}{l}\text { Middle-sized } \\
\text { city regions }\end{array}$ & $100000-$ & $\begin{array}{l}\text { Jyäskylä, Pori, } \\
\text { Kuopio, Joensuu, } \\
\text { Saimaa, Vaasa }\end{array}$ & 55225 & 54911 & 26.9 \\
$\begin{array}{l}\text { Small } \\
\text { city regions }\end{array}$ & $\begin{array}{l}\text { Less than } \\
100000\end{array}$ & $\begin{array}{l}\text { Hämeenlinna, } \\
\text { Rovaniemi, Rauma, } \\
\text { Kajaani, Savonlinna }\end{array}$ & 11958 & 11904 & \\
\hline
\end{tabular}


Table 3.

The classification of the data according to the growth of the city region. Source (population): Statistics Finland (2016).

\begin{tabular}{lllccc}
\hline $\begin{array}{l}\text { Classification } \\
\text { by the growth of } \\
\text { the city regions }\end{array}$ & $\begin{array}{l}\text { Population } \\
\text { change } \\
2000-2015\end{array}$ & City regions & $\begin{array}{c}\text { All university } \\
\text { graduates } \\
2000-2015\end{array}$ & $\begin{array}{c}\text { University } \\
\text { graduates with } \\
\text { locational data } \\
2000-2015\end{array}$ & $\begin{array}{c}\text { Share (\%) of } \\
\text { all university } \\
\text { graduates } \\
2000-2015\end{array}$ \\
\hline $\begin{array}{l}\text { Capital } \\
\text { city region }\end{array}$ & $\begin{array}{l}\text { over } \\
200000\end{array}$ & Helsinki & 67360 & 66500 & 32.8 \\
$\begin{array}{l}\text { Moderately } \\
\text { growing } \\
\text { city regions }\end{array}$ & $\begin{array}{l}25000- \\
62000\end{array}$ & $\begin{array}{l}\text { Tampere, Turku, Oulu, } \\
\text { Jyväskylä }\end{array}$ & 90068 & 89494 & 43.8 \\
$\begin{array}{l}\text { Slowly growing } \\
\text { city regions }\end{array}$ & $\begin{array}{l}3000- \\
12000\end{array}$ & $\begin{array}{l}\text { Kuopio, Vaasa, } \\
\text { Hämeenlinna, Joensuu, } \\
\text { Rovaniemi }\end{array}$ & 33036 & 32874 & 16.1 \\
$\begin{array}{l}\text { Declining } \\
\text { city regions }\end{array}$ & $\begin{array}{l}\text { Saimaa, Rauma, } \\
\text { Kajaani, Pori, } \\
\text { Savonlinna }\end{array}$ & & & \\
\hline
\end{tabular}


Table 4.

City regions' shares of the production of university graduates (master's or equivalent degree) and the shares of all the university graduates between 2000-2015 living in the city regions 1, 5 and 10 years after graduation.

\begin{tabular}{|c|c|c|c|}
\hline $\begin{array}{c}\text { Share }(\%) \text { of } \\
\text { the production of } \\
\text { university graduates } \\
2000-2015\end{array}$ & $\begin{array}{c}\text { Share }(\%) \text { of } \\
\text { university graduates } \\
\text { after } 1 \text { year }\end{array}$ & $\begin{array}{c}\text { Share }(\%) \text { of } \\
\text { university graduates } \\
\text { after } 5 \text { years }\end{array}$ & $\begin{array}{c}\text { Share }(\%) \text { of } \\
\text { university graduates } \\
\text { after } 10 \text { years }\end{array}$ \\
\hline
\end{tabular}

\begin{tabular}{lcccc}
\hline $\begin{array}{l}\text { Capital } \\
\text { city region }\end{array}$ & 32.8 & 42.3 & 42.3 & 41.3 \\
$\begin{array}{l}\text { Large } \\
\text { city regions }\end{array}$ & 43.8 & 24.1 & 23.3 & 23.1 \\
$\begin{array}{l}\text { Middle-sized } \\
\text { city regions }\end{array}$ & 16.1 & 14.3 & 13.6 & 13.4 \\
$\begin{array}{l}\text { Small } \\
\text { city regions }\end{array}$ & 6.8 & 3.9 & 3.9 & 4.0 \\
\hline
\end{tabular}


Table 5.

The migration flows (\%) of the university graduates who completed their master's or equivalent degrees during 2000-2015, between the graduation city regions and the destination city regions where they live after graduation. The city regions are classified according to their population.

Destination city regions

\begin{tabular}{|c|c|c|c|c|c|c|c|c|}
\hline & & & $\begin{array}{l}\text { Capital } \\
\text { city region }\end{array}$ & $\begin{array}{c}\text { Large } \\
\text { city regions }\end{array}$ & $\begin{array}{l}\text { Middle-sized } \\
\text { city regions }\end{array}$ & $\begin{array}{l}\text { Small city } \\
\text { regions }\end{array}$ & $\begin{array}{l}\text { Other city } \\
\text { regions** }\end{array}$ & $\begin{array}{l}\text { Outside city } \\
\text { regions*** }\end{array}$ \\
\hline \multirow{4}{*}{$\begin{array}{l}\text { After } \\
1 \text { year }\end{array}$} & \multirow{4}{*}{ 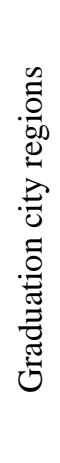 } & $\begin{array}{l}\text { Capital } \\
\text { city region }\end{array}$ & $83.9^{*}$ & 3.5 & 2.8 & 1.3 & 6.4 & 2.0 \\
\hline & & $\begin{array}{l}\text { Large } \\
\text { city regions }\end{array}$ & 20.6 & $\begin{array}{c}53.1 \\
(49.7)^{*}\end{array}$ & 5.5 & 3.7 & 8.8 & 4.9 \\
\hline & & $\begin{array}{l}\text { Middle-sized } \\
\text { city regions }\end{array}$ & 25.2 & 8.8 & $\begin{array}{c}32.0 \\
(23.9)^{*}\end{array}$ & 3.2 & 16.1 & 6.5 \\
\hline & & $\begin{array}{l}\text { Small } \\
\text { city regions }\end{array}$ & 17.4 & 20.9 & 11.2 & $\begin{array}{c}19.8 \\
(17.5)^{*}\end{array}$ & 16.5 & 12.0 \\
\hline \multirow{4}{*}{$\begin{array}{c}\text { After } \\
5 \text { years }\end{array}$} & \multirow{4}{*}{ 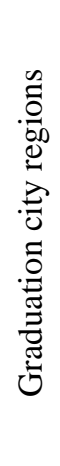 } & $\begin{array}{l}\text { Capital } \\
\text { city region }\end{array}$ & $80.3^{*}$ & 4.4 & 3.4 & 1.4 & 8.0 & 2.5 \\
\hline & & $\begin{array}{l}\text { Large } \\
\text { city regions }\end{array}$ & 22.7 & $\begin{array}{c}48.3 \\
(44.2)^{*}\end{array}$ & 6.0 & 3.9 & 9.8 & 5.3 \\
\hline & & $\begin{array}{l}\text { Middle-sized } \\
\text { city regions }\end{array}$ & 26.2 & 10.0 & $\begin{array}{c}28.1 \\
(19.7)^{*}\end{array}$ & 3.5 & 17.3 & 6.4 \\
\hline & & $\begin{array}{l}\text { Small } \\
\text { city regions }\end{array}$ & 18.6 & 21.4 & 11.4 & $\begin{array}{c}17.2 \\
(14.9)^{*}\end{array}$ & 17.6 & 11.5 \\
\hline \multirow{4}{*}{$\begin{array}{l}\text { After } \\
10 \text { years }\end{array}$} & \multirow{4}{*}{ 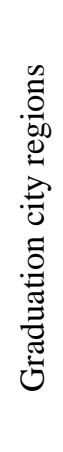 } & $\begin{array}{l}\text { Capital } \\
\text { city region }\end{array}$ & $77.3^{*}$ & 4.9 & 4.1 & 1.6 & 9.1 & 3.0 \\
\hline & & $\begin{array}{l}\text { Large } \\
\text { city regions }\end{array}$ & 23.1 & $\begin{array}{c}45.9 \\
(41.4)^{*}\end{array}$ & 6.2 & 4.0 & 10.5 & 5.8 \\
\hline & & $\begin{array}{l}\text { Middle-sized } \\
\text { city regions }\end{array}$ & 25.3 & 10.8 & $\begin{array}{c}25.9 \\
(16.9)^{*}\end{array}$ & 3.7 & 18.4 & 6.9 \\
\hline & & $\begin{array}{l}\text { Small } \\
\text { city regions }\end{array}$ & 17.9 & 21.7 & 12.3 & $\begin{array}{c}15.4 \\
(13.3)^{*}\end{array}$ & 19.4 & 11.1 \\
\hline
\end{tabular}

* The share $(\%)$ of the university graduates who stayed in the graduation city region, ** 'Other city regions' refers to the city regions which do not have university units or they provide only small-scale university education, *** 'Outside city regions' refers to the areas located outside the administrative city regions (i.e. small towns and rural areas). 
Table 6.

The migration flows (\%) of the university graduates who completed their master's or equivalent degree during 2000-2015, between the graduation city regions and the destination city regions where they live after graduation. The city regions are classified according to their population change.

Destination city regions

\begin{tabular}{|c|c|c|c|c|c|c|c|c|}
\hline & & & $\begin{array}{l}\text { Capital } \\
\text { city region }\end{array}$ & $\begin{array}{l}\text { Moderately } \\
\text { growing } \\
\text { city regions }\end{array}$ & $\begin{array}{c}\text { Slowly } \\
\text { growing } \\
\text { city regions }\end{array}$ & $\begin{array}{l}\text { Declining } \\
\text { city regions }\end{array}$ & $\begin{array}{l}\text { Other city } \\
\text { regions } * *\end{array}$ & $\begin{array}{l}\text { Outside city } \\
\text { regions**** }\end{array}$ \\
\hline \multirow{4}{*}{$\begin{array}{l}\text { After } \\
1 \text { year }\end{array}$} & \multirow{4}{*}{ 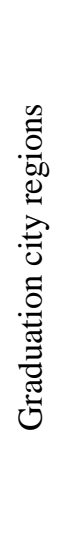 } & $\begin{array}{l}\text { Capital } \\
\text { city region }\end{array}$ & $83.9 *$ & 3.5 & 2.1 & 1.3 & 6.4 & 2.0 \\
\hline & & $\begin{array}{l}\text { Moderately } \\
\text { growing } \\
\text { city regions }\end{array}$ & 21.4 & $\begin{array}{c}54.7 \\
(48.7)^{*}\end{array}$ & 4.9 & 3.5 & 10.2 & 5.4 \\
\hline & & $\begin{array}{l}\text { Slowly } \\
\text { growing } \\
\text { city regions }\end{array}$ & 22.4 & 13.3 & $\begin{array}{c}36.1 \\
(30.9)^{*}\end{array}$ & 4.6 & 15.5 & 8.2 \\
\hline & & $\begin{array}{l}\text { Declining city } \\
\text { regions }\end{array}$ & 26.9 & 13.4 & 6.0 & $\begin{array}{c}27.7 \\
(22.3)^{*}\end{array}$ & 19.5 & 6.5 \\
\hline \multirow{4}{*}{$\begin{array}{l}\text { After } \\
5 \text { years }\end{array}$} & \multirow{4}{*}{ 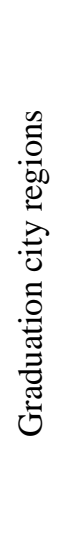 } & $\begin{array}{l}\text { Capital } \\
\text { city region }\end{array}$ & $80.3^{*}$ & 4.4 & 2.5 & 1.5 & 8.0 & 2.5 \\
\hline & & $\begin{array}{l}\text { Moderately } \\
\text { growing } \\
\text { city regions }\end{array}$ & 23.2 & $\begin{array}{c}50.7 \\
(43.8)^{*}\end{array}$ & 5.2 & 3.7 & 11.4 & 5.7 \\
\hline & & $\begin{array}{l}\text { Slowly } \\
\text { growing } \\
\text { city regions }\end{array}$ & 23.3 & 14.4 & $\begin{array}{c}33.1 \\
(27.9)^{*}\end{array}$ & 4.8 & 16.4 & 8.0 \\
\hline & & $\begin{array}{l}\text { Declining city } \\
\text { regions }\end{array}$ & 27.9 & 14.1 & 6.9 & $\begin{array}{c}24.5 \\
(18.8)^{*}\end{array}$ & 20.2 & 6.3 \\
\hline \multirow{4}{*}{$\begin{array}{l}\text { After } \\
10 \text { years }\end{array}$} & \multirow{4}{*}{ 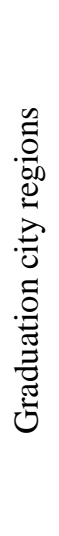 } & $\begin{array}{l}\text { Capital } \\
\text { city region }\end{array}$ & $77.3^{*}$ & 4.9 & 2.9 & 1.7 & 9.1 & 3.0 \\
\hline & & $\begin{array}{l}\text { Moderately } \\
\text { growing } \\
\text { city regions }\end{array}$ & 23.4 & $\begin{array}{c}48.7 \\
(41.3)^{*}\end{array}$ & 5.3 & 4.1 & 12.2 & 6.3 \\
\hline & & $\begin{array}{l}\text { Slowly } \\
\text { growing } \\
\text { city regions }\end{array}$ & 22.5 & 15.4 & $\begin{array}{c}30.8 \\
(25.4)^{*}\end{array}$ & 5.0 & 18.1 & 8.1 \\
\hline & & $\begin{array}{l}\text { Declining city } \\
\text { regions }\end{array}$ & 26.2 & 16.1 & 7.1 & $\begin{array}{c}23.3 \\
(17.0)^{*}\end{array}$ & 20.8 & 6.6 \\
\hline
\end{tabular}

* The share $(\%)$ of the university graduates who stayed in the graduation city region, ** 'Other city regions' refers to the city regions which do not have university units or they provide only small-scale university education, *** 'Outside city regions' refers to the areas located outside the administrative city regions (i.e. small towns and rural areas). 

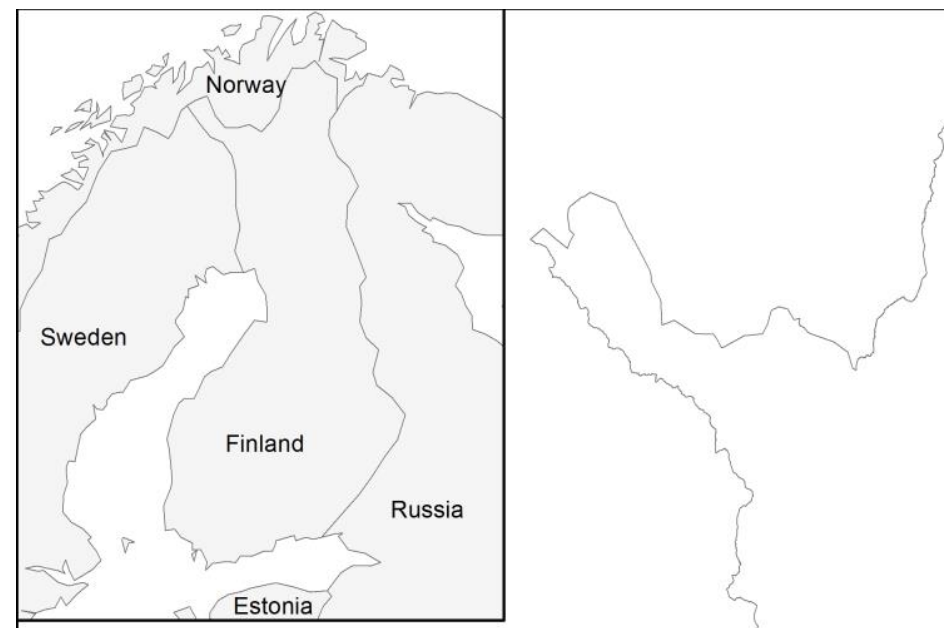

University

Other university unit

City region

Source: Boundaries of city regions

- National Land Survey of Finland

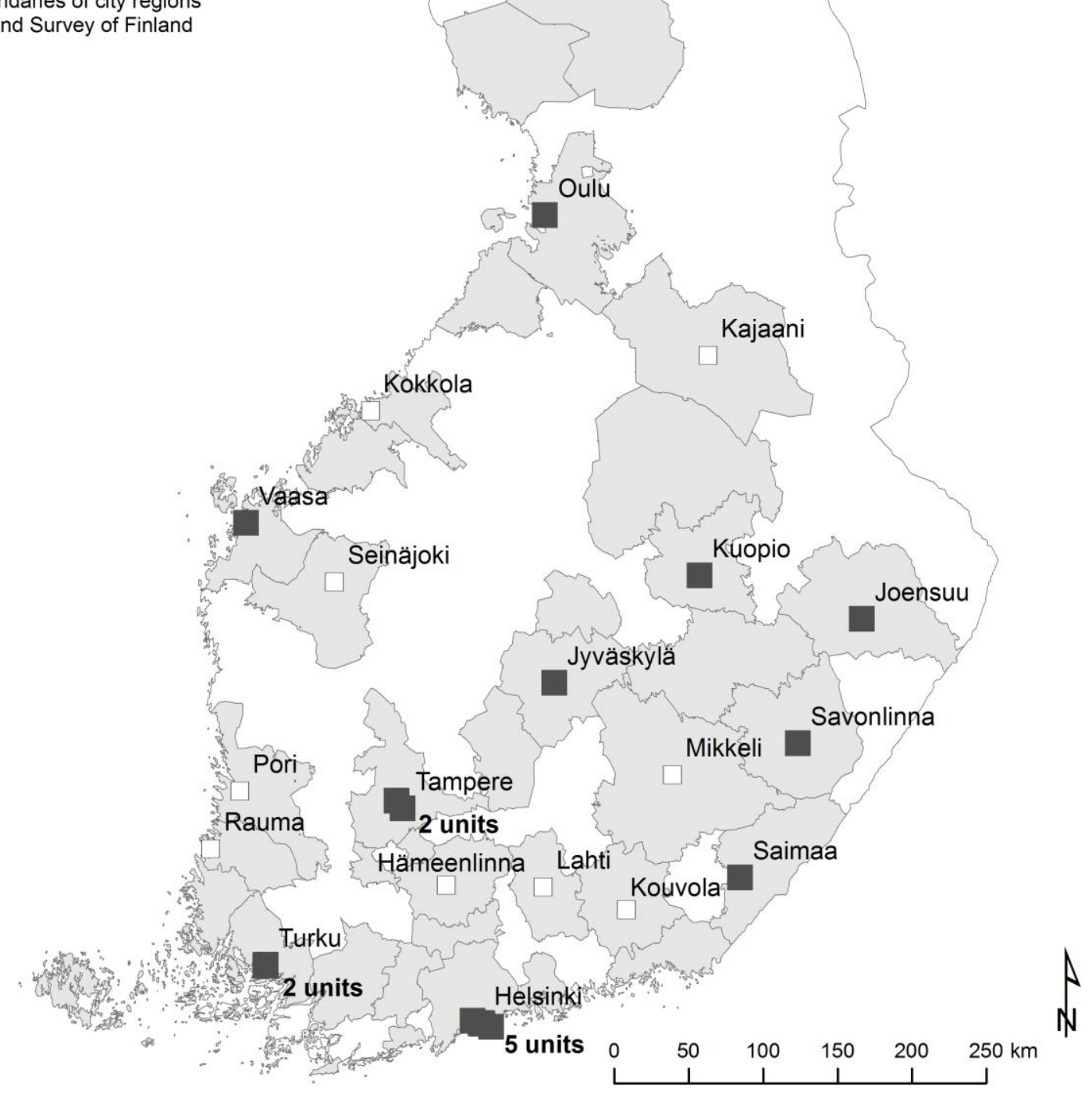

Fig.

1. Location of Finnish university units. Finland's 14 universities have campuses in 11 city regions. In addition, other university units operate in nine city regions that do not have their own universities. 


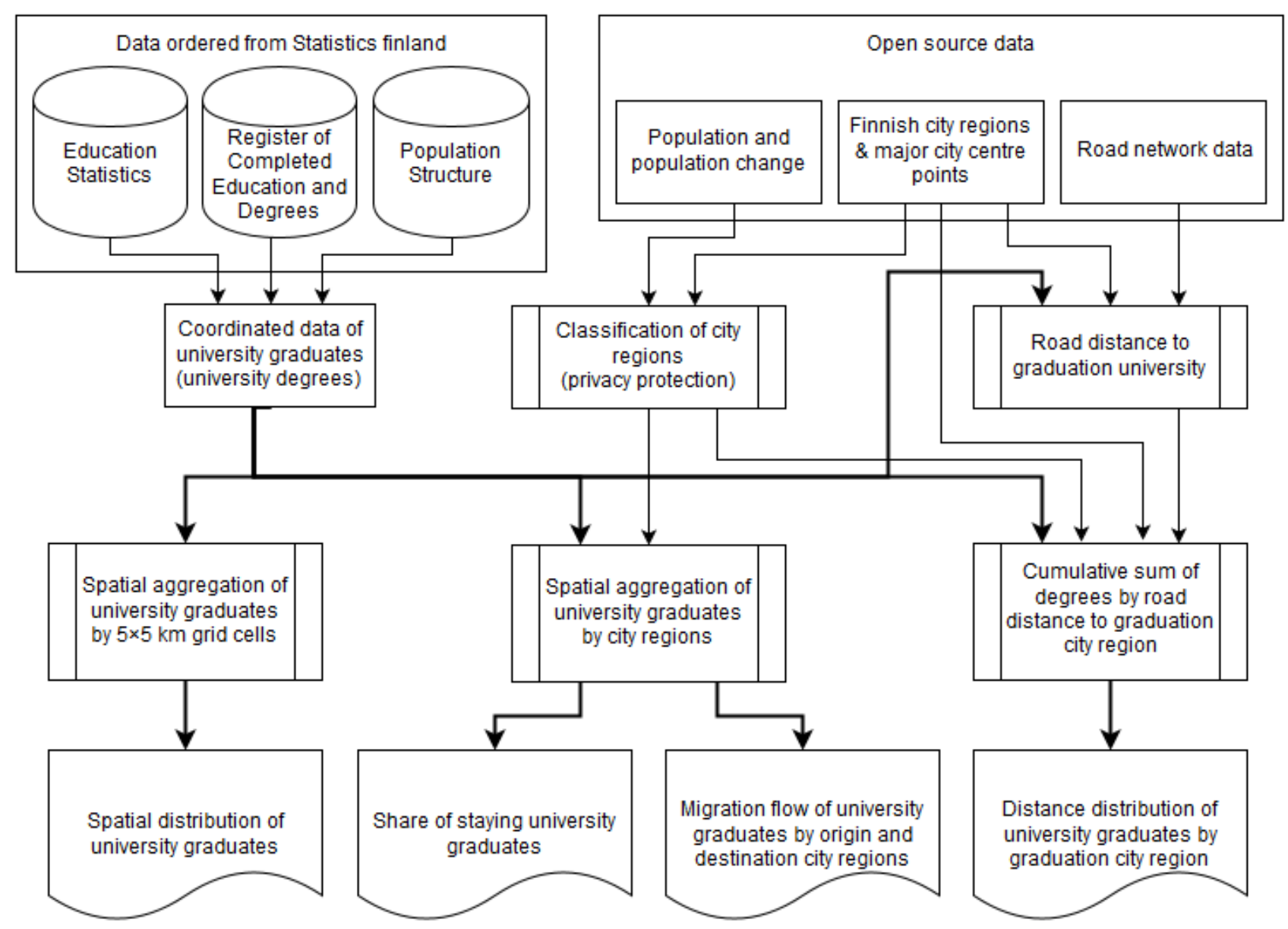

Fig. 2. Schematic work flow of the data sources, the data management, the key analyses and the results. 


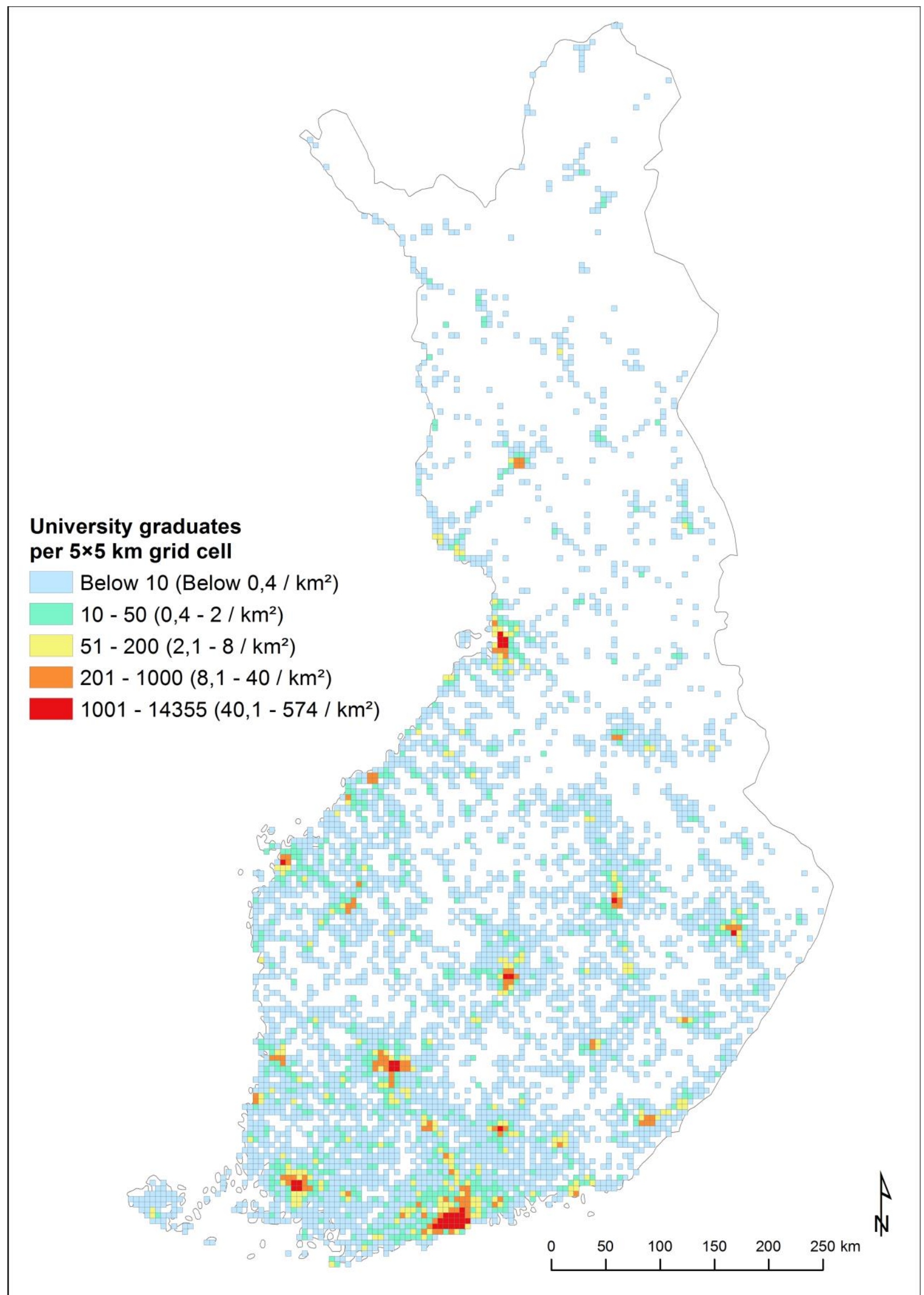

Fig. 3. Geographical distribution of the university graduates, who completed their master's or equivalent degree between the years 2000-2015, in $2015(N=203865)$. 


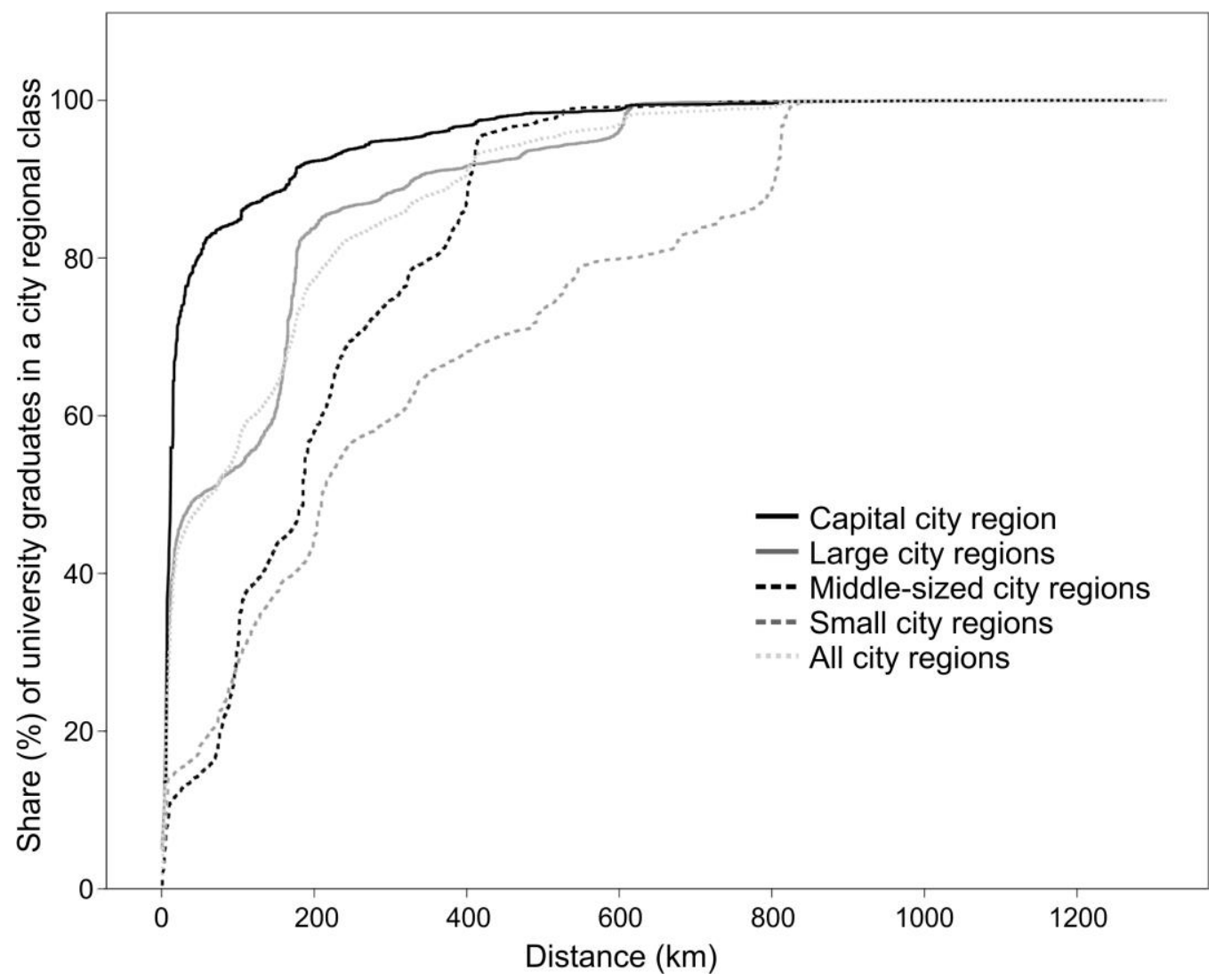

Fig. 4. Cumulative share of university graduates within aggregation groups in relation to the distance between the residential location in 2015 and the centre of the graduation city.

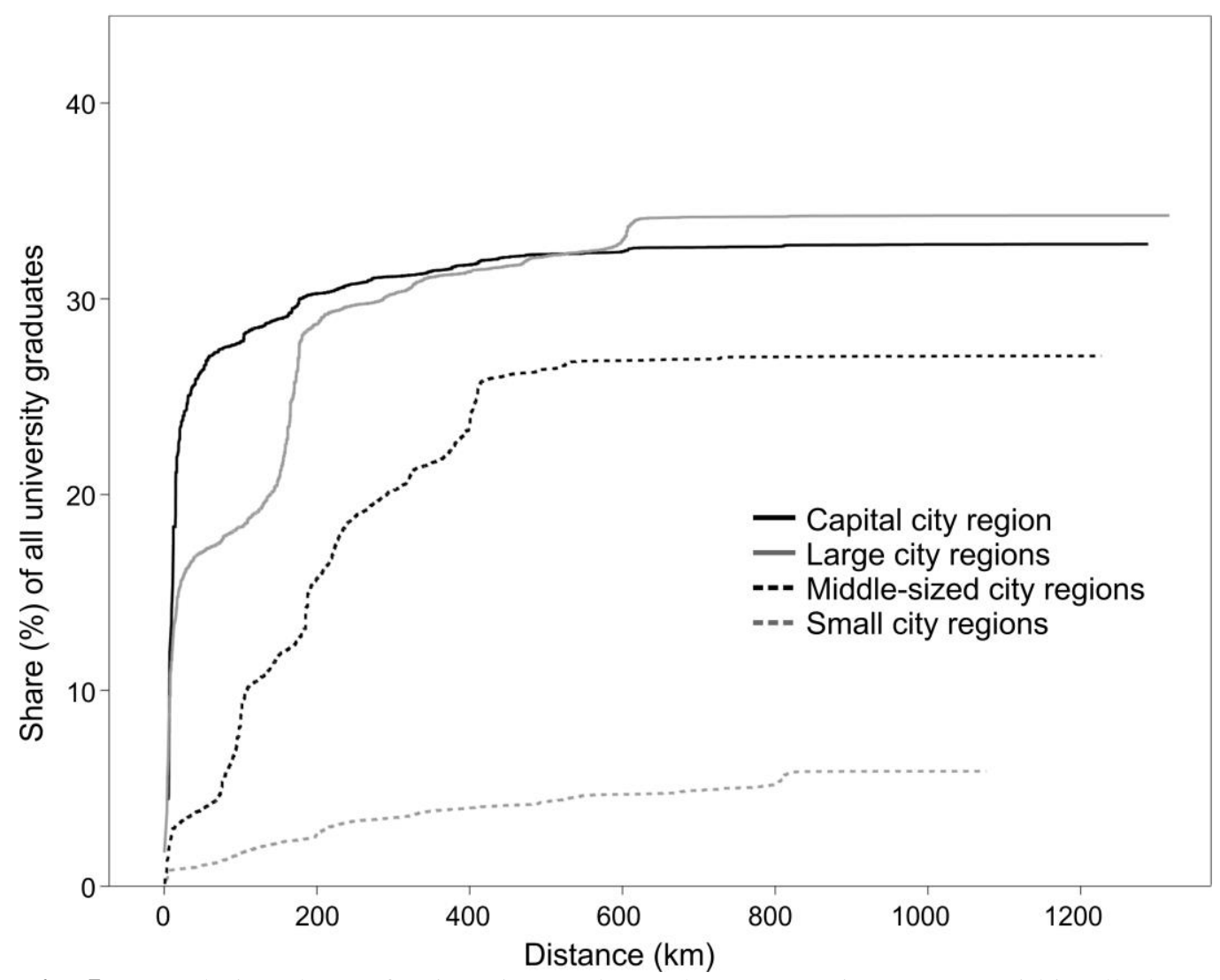

Fig. 5. Cumulative share of university graduates by aggregation groups within all observations in relation to the distance between the residential location in 2015 and the centre of the graduation city. 